\title{
Fundamental Analysis VS Technical analysis: The Comparison of Two Analysis in Malaysia Stock Market
}

\author{
Shaharudin Jakpar, Michael Tinggi, Akmal Hisham Tak and Chong Wen Yi \\ Faculty of Economics and Business, Universiti Malaysia Sarawak (UNIMAS)
}

\begin{abstract}
This study is conducted to analyse the credibility of the fundamental analysis and technical analysis on predicting the stock return and compare both models to determine which model is more credible to be used as a good trading strategy by investors. The study is based on 80 companies selected from Bursa Malaysia in the food manufacturing industry in the main market from the year of 2012 to 2016. The stock return is used to measure whether both analyses are able to forecast and generate the positive return. Net profit margin, price earnings ratio and total asset turnover are used as fundamental indicators while moving average convergence divergence is used as technical analysis indicators. In order to test the significance of both model on stock return, panel regression models are applied in this study. The result shows that although both model can be used to generate positive return, technical analysis did not outperform fundamental analysis in the food manufacturing industry in Bursa Malaysia.
\end{abstract}

Keywords: Fundamental analysis, Technical analysis, Stock return, Trading strategy, Investors, Bursa Malaysia.

\section{INTRODUCTION}

A stock market is a virtual form intermediation where buyers and sellers can trade their assets such as shares and company securities (Reilly \& Keith, 2012). Stock market has play a crucial role which determine the price of underlying assets at any particular time by matching all the available information. When there are buyers and sellers who are willing to participate in trade in an asset, stock market works. High demand of an asset will cause the value of the asset to rise. The first stock market was initially developed in London in 1606 which means the stock market has roughly over 400 year of histories. Today, due to the advancement of technology, the stock markets have risen to become extensive exchanges of capital and funding, trading in trillions $24 / 7$ across the world.

Stock markets have transformed globally over the past few centuries. Traders can trade their asset all over the world. There are around 60 exchange stock markets in the world. According to Worlds Federal of Exchange monthly report of 2015, there are 16 major exchange stock market which has market capitalization of over US \$ 1 trillion each which are New York Stock Exchange, NASDAQ, London Stock Exchange Group and etc. According to report of Capital group in October 2016, the performance of US stock has weakened due to the rise of interest rate. The standard and poor's 500 composite index slipped 2\%; Dow Jones Industrial Average declined by $1 \%$; NASDAQ composite index decreased by $2 \%$. Moving to Europe market, although European stocks has gained $0.3 \%$ overall, it had been offset due to the departure of United Kingdom from European Union. For Asian-Pacific, Japanese Yen depreciated 4\% against the U.S dollar which caused the Japanese equities rose. Besides, weakening yen caused the shares of Japanese exports to rise. Financial sectors had the best performances among all sectors which gain 9\%. However, emerging markets stocks have a decreasing trend and pulled back to an increasing trend. This scenario is due to the increase of US interest rate and outcome of the US presidential election.

As the stock markets change dramatically, securities analysis is one of the important issue for investors to determine the market trend and to reduce gambling aspects of investing (Hooke, 2010). 
Generally, there are two common types of analysis that are usually used by investors which are fundamental analysis and technical analysis. Both of them can be used to determine the value of a stock and also forecast the future performance of the stock. However, fundamental analysis analyzes the intrinsic value of a particular stock while technical analysis predicts when is the best time for investors to buy and sell the stock. According to Oberlechner (2001), most traders used both fundamental and technical approaches to make their financial decision in Europe countries which are London, Vienna and Zurich. However, traders from London used fundamental more often whereas traders from Vienna and Zurich use a significant more technical analysis approach. Another survey that studies traders in US market found that $30 \%$ of traders which could be characterized as technical analysts and traders who are using technical analysis is increasing. (Cheung \& Ching, 2001).

Moving to Nigeria, most of the Nigerian traders use fundamental analysis to evaluate the value of share. $80 \%$ of the USA and UK analysts who participated in the survey used fundamental analysis such as $\mathrm{P} / \mathrm{E}$ ratio to forecast the market value whereas technical analysis is ranked as second choices (Tijjani\& Power, 2009). However, for emerging market, investors choose fundamental analysis as their main approach while technical analysis was ranked as second when they make their investment decision (Al-AbdulQader et al, 2007). Another similar survey conducted by Wang et al (2007) in China. Based on their finding, there are $80 \%$ of respondents that preferred fundamental analysis, while $44 \%$ of the respondents preferred technical analysis. Technical analysis is profitable when applied in Singapore stock market. Hence, most of the investors rely heavily on technical analysis. (Wong et al, 2003).

Based on all these previous studies shown that traders from different location will have different trading philosophies. Even though the information is provided symmetries among different countries, they will have different interpretation and have different expectation on it. Therefore, different countries tend to have different preferences on investment strategies due to cultural differences in every country. Hence, this research is to investigate which approach (fundamental analysis or technical analysis) is more credible to assist investors in forecasting the movement of stock in Malaysia stock market.

The stock market in Malaysia known as Bursa Malaysia. It is a visual platform where market participants trade their financial instrument such as equities and derivatives. There are various products and services which provide by Bursa Malaysia such as equities, derivatives, bonds and etc. However, there are two types of markets which are Main market and Access Certainty Efficiency Market (Ace). Both of them consists of 808 companies and 113 companies respectively. It operates under the supervision of Securities Commission. In 2015, Bursa Malaysia was ranked 12th as most competitive country in the world. According to Bursa Malaysia, the market capitalization had achieved RM1.69 trillion as at 30 September 2016 which has increase 5.6\%. In 2006, FTSE group collaborated with Bursa Malaysia to provide a suite of indices for Malaysia Market. There are lots of indices can be used as a benchmark of the performance of the stock in various sectors and segments. The most common that used by investors to gauge the overall market performance and economic development is known as FTSE Bursa Malaysia KLCI which is also known as FBM KLCI. It is a capitalization-weighted stock market index which form by 30 largest market capitalization listed companies in Bursa Malaysia. All these companies need to fulfill the eligibility requirement which set by FTSE and Bursa Malaysia. Every 15 seconds, the values of FBM KLCI will be calculated and disseminated to provide a continuity of KLCI index value. Thus, historical movement of the Malaysian stock market can be preserves. It is essential for investors to understand and familiar with stock market index. It assists investors to make their financial decision on time through anticipate the performance of the stock market without rely on speculation. According to annual report of Bursa Malaysia, the share price closed at RM 8.35 on 31 December 2015 which has increased 3\%. The highest price is RM9.00 on 24th April 2015. However, compared to FBM KLCI, the share price performance of Bursa Malaysia is better. This is due to depreciation of Ringgit, depressed commodity price, a slowdown of China economy, and higher interest 
rate in the US which lead to capital outflow. The figure 1 below shown the comparison of Bursa Malaysia share price performance and FBM KLCI.

Figure 1: Share Price Performance vs FBM KLCI

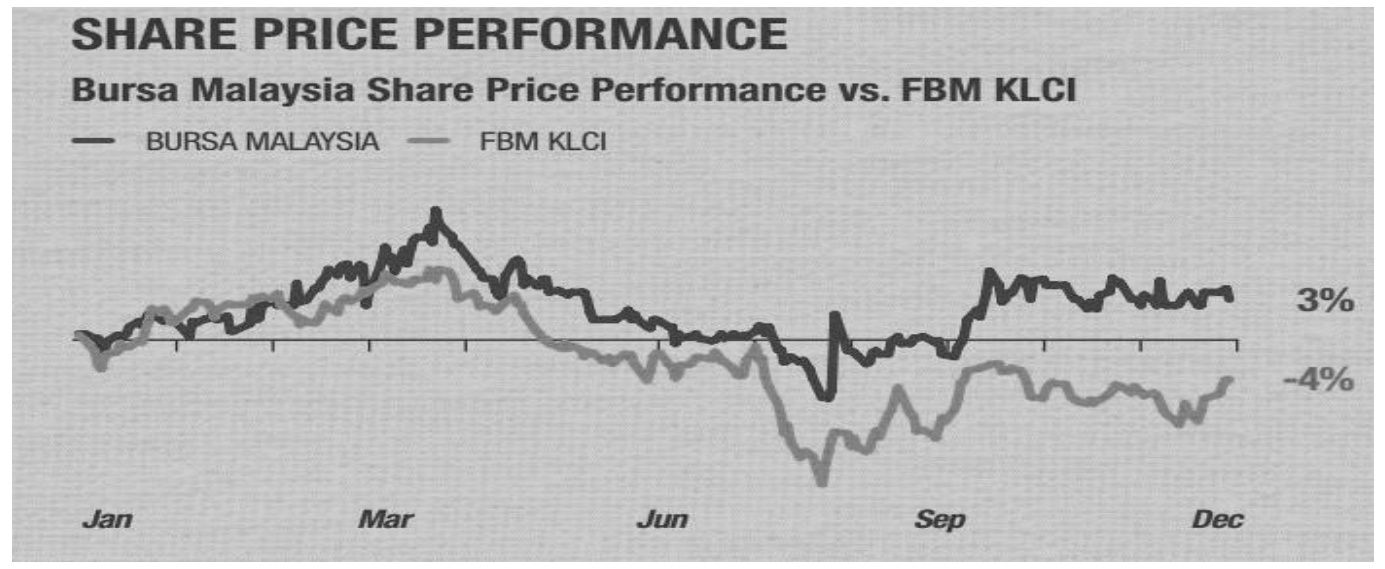

Source: Bursa Malaysia Annual Report 2015

In 2015, the movement of the share is quite volatile which can be proved through the zip- zap graph in the figure 2 below. In January, there is a decreasing trend from 5 January 2015 - 6 January 2015 due to concern over decreasing crude oil prices and potential of Greece's exit from Eurozone dampen sentiment. On 9 March 2015 to 10 March 2015, rising interest rate of US and failing crude oil prices had brought the market down turn. On 21 April 2015, FBM KLCI had closes at its highest level for 2015 which is $1,862.80$ points. However, the graph showed a decreasing trend which is caused by several events. Those events were prime minister unveils the 11th Malaysia Plan, rise of interest rate of US and possibility of a Greek debt default. Nevertheless, the trend drops dramatically in August 4 to 24 and pulled back to an increasing trend in August 25 to 28. According to the annual report of Bursa Malaysia, the decreasing trend is due to devaluation of Chinese Yuan with depreciation of Malaysian Ringgit and weakening of crude oil and commodity price and it turn to increasing trend when the announcement of decision of Chinese government and US Federal Reserve to hold the interest rate. It can be concluded that the overall performance of Malaysia stock market in 2015 is not idealistic compared to 2014 .

Figure 2: Daily Open and Closing Price of FBM KLCI and the Trading Volume, 2015- 2016

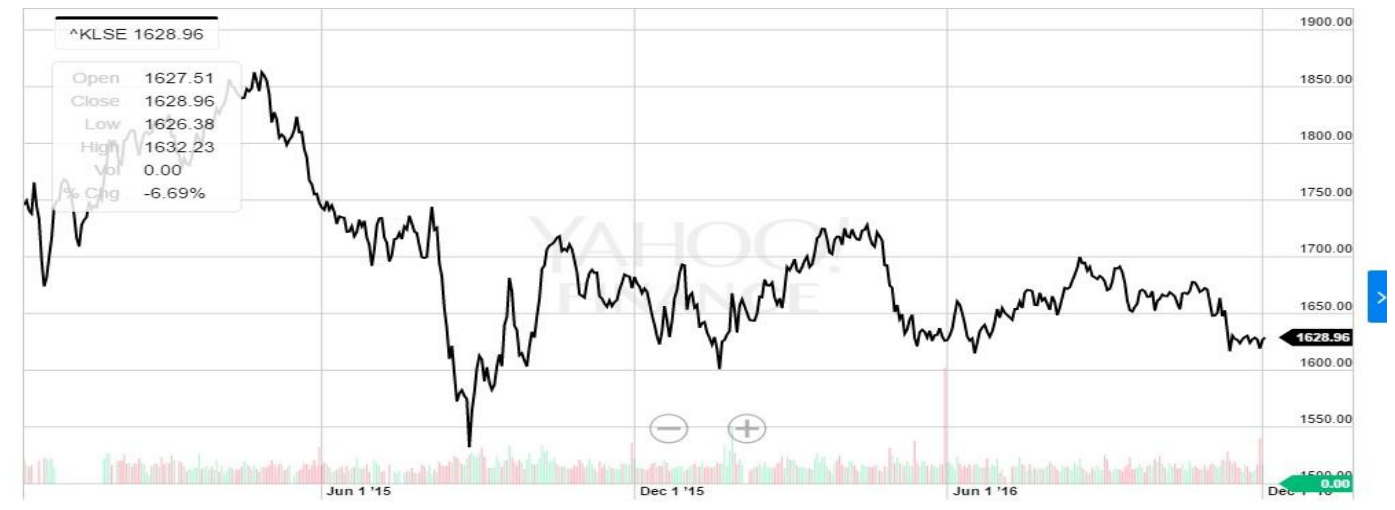

Source: Yahoo Finance 2016 
Vol. 1 No. 12018

Fundamental analysis is known as the cornerstone of investing which is used to evaluate intrinsic value of a security (Drakopoulou, 2015). It evaluates a security by examining the underlying forces which can affect the value of security such as macroeconomic factors. The main objective of the fundamental analysis is to forecast future earnings and the true value of the security so that investors can make investment decision on time to gain profit (Suresh, 2013). There are three phases to examine the fundamental analysis which can be known as EIC (economy-industry-company) framework or top-down approach. (Suresh, 2013). These three phases have derived a current fair value of stock and predicting the future value. Firstly, for economic level, economic indicators such as inflation rate, interest rate, unemployment rate, and monetary policy are used to assess the growth of the national economy. Undoubtedly, the overall economy is closely related to the stock market, the movement of economy directly affects the stock market condition (Ozlen\& Ergun, 2012). When the economy is performing well, investors tend to anticipate the stock to perform as well. For industry level, competitive analysis of industries and industry life cycle analysis have been identified in order to assess the prospects of various industry groupings (Suresh, 2013). At company level, fundamental analysis deals with the financial statement, management, business concept and all other aspects of the company to get more insight on the growth and performance of the company. Historical accounting data such as profitability, leverage, activity and efficiency ratio reveals the performance and the value of the company (Nadeem\& Muhammad, 2013). It is commonly used by investors to analyze financial status of a company.

Before making an investment decision, investors should evaluate the three phases of fundamental analysis. This is due to each share will have their intrinsic value which are based on its present and future earning capacity. A comparison of the intrinsic value of the share and the prevailing market price can be done to arrive at an investment decision. If the current stock price is not equal with the intrinsic value, the stock is either overvalued or undervalued thus investors can gain their profit through buying those undervalued stock which the intrinsic value of the stock is higher than market value (Drakopoulou, 2015). This is due to the price of such a share is expected to move up in future in order to match with its intrinsic value. An analytical framework which based on the information of the company, the industry that company belongs and the overall economy is provided for investors to assists their rational investment decision-making. However, valuation techniques used differ in different industry groups and different companies (Petrusheva\&Jordanoski, 2016). Although the value of a share can be evaluating by fundamental analysis, investors should be cautious while analyzing it. Some research might be written by a sell-side analyst or press releases and corporate statements of a company that announces good news. Therefore, investors should be alert and become skilled readers to ignore the hype and focus on the important information (Suresh, 2013)

Technical analysis is also known as "charting" which uses different types of charts that show past price movement to predict the future financial price movement (Lo el al, 2000). Technical analysis does not calculate intrinsic value of a stock and only study on the behavior of the market which only focuses on the price action (Venkatesh \& Tyagi, 2011). Based on the concept of technical analysis, demand and supply is the main factor that affects the price of a stock. (Suresh, 2013). It means that a higher price reflects an increase in demand whereas lower prices reflects there is an increase in supply. The aim of Technical analysis is to help investors to determine the best time to buy and sell the sock by spotting demand and supply levels as well as breakouts in the chart. (Petrusheva \& Jordanoski, 2016). Technical analysis is based on three premises which are shown in the following (Mitra, 2011).

- All relevant information is discounted and already price-in in stock price

- Movement of prices tend to follow the trends

- Historical of the price movement often repeat.

There are some tools and techniques that have been developed by technical analyst to study the past pattern of stock price movements and forecast future movements. Basically, the tools and 
techniques were developed based on prices, time, volume and width. (Suresh, 2013). There is variation of techniques of technical analysis such as chart analysis, pattern recognition analysis, seasonality and cycle analysis and computerized technical trading system (Park \& Irwin, 2004). Technical analysts normally used those tools and techniques to trade in the stock market. Moving average is one of the popular technical analysis often used by investors and also technical analysts. There are three types of moving average which are simple, weighted and exponential. A moving average is a smooth presentation of underlying historical prices by calculate the average price of the stock in a specific period of time. It can be tailored in any time frame. The common moving average lengths are 10, 20, 50, 100 and 200, thus it is suitable for long-term and short term investors (Suresh, 2013).

There is a moving average strategies to determine the buy and sell signal which is crossover method. The most basic type of crossover is when the prices passes through the moving average or when the prices moves from one side of moving average and closes on the other. The crossover prices can be used as a basic entry or exit strategy. However, there is another strategy of moving average that involves two moving average to create buy and sell signals which is one longer moving average and one shorter moving average (Mitra, 2011). Golden cross is known as buy signal whereas death cross is known as sell signal. Golden cross takes place when the short-term moving average crosses above the long-term moving average which is also known as upward momentum. On the other hand, death cross takes place when the short-term moving average crosses below the long-term moving average which is also known as downward momentum. Technical analysis is using simple logic and application to forecast future profit without analyzing the factors that have impact on the overall economy, industries and companies. It only focuses on the movement of historical stock price and the volume traded. Technical analysis can be done with the help of computer tools which is easier for investors to use. Some may argue that technical analysis cannot be valid due to lack of academic or scientific confirmation. (Petrusheva \&Jordanoski, 2016). However, there are many previous studies has proved that technical analysis is both useful and profitability (Metaghalchi et al, 2012).

Fundamental and technical analysis are the most common method used by market participants in the stock market as it manages to deal with the dilemma that are faced by those participants (Chauhan, 2014). The approaches used in fundamental and technical analysis does not overlapped but both of them seem to be converging. (Constable, 2016). Some analysts may think that technical analysis is the substitute of the fundamental analysis. However, in a study stated that both of them can complement to each other in order to capture above-average return (Bettman and Sault, 2009). The main difference between fundamental analysis and technical analysis is the way they are used to predict a value of securities. Fundamental analysis studies the overall performance of the economy, industry and the company in order to determine the fair value of stock and compare it with market values, thus identifying the investment opportunities (Wafi et al, 2015b). However, technical analysis studies about the market which only focus on the movement of the share price. It does not consider the economic factors or the fair value of the stock, what matters is the pattern of the chart which is created by the demand and supply. Thus, get the insights from it and get into and exit the market in the most appropriate time (Petrusheva \& Jordanoski, 2016).

The basic principle of both method is different which cause the way of working different. Fundamental analysts believe that the market do not reveal the true value of the stock accurately at any given moment, some stock might be overvalued or undervalued. On the other hand, technical analysts consider all relevant information has reflected on the stock price, the movement of the stock price tend to repeat themselves in the future. However, the main criticism toward the fundamental and technical analysis derives from the economic theory which is efficient market. According to efficient market theory, all the information is already reflected to the current stock price thus stock will always trade at their fair value. It is impossible to outperform the market and obtain profit from it (Clark et al, 2001). Thus, it suggested that it is pointless to use fundamental and technical analysis. However, there are 
many researchers that argue about it and had shown that it is possible to outperform the market and generate profit from it. For example, Warren Buffett is beating the market consistently over long periods of time. (Paul, 2016).

The main purpose of this study is to investigate the credibility of fundamental analysis and technical analysis on forecasting stock price and abnormal return gained by investors. This research seeks to examine which techniques is more credible and preferable in predicting the stock return in Malaysia stock market between fundamental analysis and technical analysis? It is a question that has been asked for past decades. Do fundamentals and technical analysis capture the similar stock return in the data? Which has more predictive power, fundamental analysis or technical analysis? In Bursa Malaysia, there are over hundreds of listed companies in various sectors that can be invested on, it is a difficult task to choose which stock to put their funds in and trade. Therefore, there are some aspects that investors should determine in order to generate the maximum profit from their investment. This study helps investors, portfolio's managers and Brokers in financial decision making by applying the better approach of analyzing the movement of stock in Malaysia stock market.

\section{LITERATURE REVIEW}

\section{Fundamental analysis}

Fundamental analysis is well known in examine how well does a company perform in the industry and forecast future earnings and stock price of a company. According to a survey that is conducted by Jagongo and Mutswenje (2014), fundamental analysis of a company is one of the important factors that affect individual investment decision. Fundamental factors is considered as the main factors that affects the movement of the stock return (Hou et al, 2011). It can be used to predict the future earnings or return. However, there are several papers which support the predicting power of fundamental analysis. In the prior studies, Ou and Penman (1989) suggested that abnormal return can be predicted by using fundamental analysis. 68 accounting descriptors that can be used to describe leverage, activity and profitability of the firm was reduced in several stages to calculate the summary value of measure $\left(\mathrm{P}^{\wedge}\right)$. Thus, the $\mathrm{P}^{\wedge}$ is used to predict stock return. Through the research, they found that fundamental signals have the predicting power. Abarbanell and Bushee (1998) has done a similar research and get the same result which stated that fundamental analysis can be used to predict abnormal return by using different approach from $\mathrm{Ou}$ and Penmen research. They used the accounting ratio that consists of conceptual and theoretical background where Ou and Penmen (1989) did not include in their studies. They focus on individual signal to evaluate the strength of predictive power of each signal instead of combine the predictors into a summary measure. Therefore, the contextual that influence their credibility can be investigated.

Besides, Kheradyar, Ibrahim and Mat (2011) studied the ability of financial ratio to predict the stock returns. Three financial ratio are dividend yield, earning yield and book-to- market ratio. Least square technique and multiple regression were used in the research. It showed that three of them can be used to forecast stock return. However, Book-to-market value showed higher predicting power than the other two. Similar findings are those of Sharma (2011) suggested that earning per share, dividend per share and book value per share have significant influence on the stock price. Different from result of Kheradyar, Ibrahim and Mat, she found that the strongest determinants of stock price are dividend per share and earning per share. Almumani (2014) studied the quantitative factors (dividend per share, earning per share, book value per share and price earnings ratio) that give an impact on stock prices. Linear multiple regression and correlation have been selected to explain the relationship between them. The result show that all of them have positive correlation with market price.

Asif, Arif and Akhbar (2016) investigated the predicting power of accounting information and the share price by using OLS regression method. The accounting ratio included EPS, book value per share, 
capital employed per share and operating cash flow per share. Their finding showed that accounting information parameter have joint explanatory power to forecast the stock price. On the other hand, there are some studies that did not support the predicting power of fundamental analysis on stock return. Sharma and Preeti (2009) suggested that fundamental analysis has statistically insignificant relationship with stock returns. Profitability of firm, cash performance, operating efficiency and liquidity are the fundamental signals that are used in the research, F-score is calculated and found that there is an insignificant relationship between fundamental signal and stock return of firm. A similar research is studies by Nadeem, Sajid and Muhammad (2013). They found that fundamental analysis has no predicting power on stock return for non-financial sectors in Pakistan. Five fundamental signals which are leverage ratio, profitability ratio, efficiency ratio, liquidity ratio and market based ratio have been tested by using simple regression in this research. They suggested that fundamental analysis is insufficient for forecasting stock, combination of fundamental analysis and technical analysis will have more predicting power in stock return. Fundamental analysis is widely used by investors to forecast the movement of stock price. It examines all the factors that will give an impact on the stock return including micro and macroeconomic factors. The macroeconomic factors such as monetary policy, inflation, unemployment rate, gross domestic product and etc. (Suzana, Sinisa \& Zoran, 2013).

\section{Technical Analysis}

Technical analysis is a forecasting method to predict movement of stock price by using forecasting techniques such as pattern recognition analysis and chart analysis without referring to economic or fundamental analysis. (Murphy, 1999) There are some evidence that technical analysis has predictive power on stock return. Brock, Lakonishok and LeBaron (1992) examined two trading rules which are moving average and trading range break on the Dow Jones Industrial Index from 1897 to 1986. Based on their finding, they stated that trading rules has predictive power. Another study in 1995, Bessembinder and Chan found that the technical analysis has predictive power in the emerging markets of Asian (Malaysia, Thailand, Taiwan, Hong Kong and South Korea). The finding of Bessembinder and Chan has been supported by Metghalchi et al (2009) by apply moving average rules in Hong Kong, Singapore, South Korea and Taiwan and get the same conclusion which is stock return can be predicted by moving average rule. According to Lo, Mamaysky and Wang (2000), technical analysis provides incremental information which can add value to the investment process and may have some practical value. Nonparametric kernel regression has been used to recognize the technical pattern and extracting nonlinear pattern from noisy data to identify regularizes in the time series of prices. They also suggested that automated algorithms can be used to improve the technical analysis. In 2012, Metaghalchi, Chang and Xavier studies the profitability of technical trading rules by using 9 technical indicators. A null hypothesis of equality of the mean buy with mean sell days has been stated. They found that 58 out of 66 trading models reject the null hypothesis. Their finding provide evidence that there is a predictive power of technical trading rule on stock.

Park and Irwin (2007) has studies on the profitability of technical analysis by reviewing previous studies. The previous studies have divided into two group which are earlier studies up to 1988 and modern studies 1988 until 2004. Both of the studies support predictive power of technical analysis. However, for earlier studies there is profitability of technical trading strategies in foreign exchange market and future market but not in stock market whereas for modern studies technical trading strategies is profitable for stock market at least until the early of 1990. They also found that most of the empirical studies has faced problem in testing procedure such as data snooping, ex post selection of trading rules and difficult to estimate the risk and transaction cost. In 2006, Qi and Wu had further studied about the profitability of technical trading rule. They evaluated the 2,127 technical trading rules by employing reality check and the results showed that there are data-snooping biases, potential structure change which made the evidence of trading rule probability becomes weaker in the most recent period. Thus, they suggested that the foreign market becomes more efficient over time. In contrast, there are some 
studies that do not support predicting power of technical analysis. Hudson, Dempsey and Keasey (1996) applied the trading rules in United Kingdom data and concluded that technical analysis has no predictive power in stock return and do not produce return after deducting transaction costs. Coutts and Cheung (2000) investigated moving average oscillator and trading break-out rules in Hang Seng Index on Hong Kong stock exchange. Their finding showed that moving average oscillator and trading Break-out rules fails to generate abnormal returns. Mckenzie (2007) studies the usefulness technical trading strategies to forecast stock market movement in seventeen emerging market. He found that there is no useful technical trading strategy to forecast stock market when applied to U.S. data. From his finding, market condition which is depth of the market and trading volume are the factors that affect the predictive power of trading rule. Lento, Gradojevic and Wright (2007) proposed that the technical analysis is not profitable against Bollinger Bands indicators after deducting the transaction cost. Through the result, out of 12 test, Bollinger Bands has profitable in only 2 tests and there is no superior performance exhibited. Metghalchi, Chang and Marcucci (2008) examined the probability of getting profit from some moving average trading rule in Swedish stock market from 1986 till 2004 period. The finding indicated that moving average have predicting power. Although there are accounting data snooping problem and high transaction cost, it can still outperform the buy and hold strategy.

However, an opposite result show in Karachi stock exchange market, Sohail and Jehanzeb (2015) evaluated the performance of technical analysis by using moving average as a tool. They suggested that the returns from technical analysis cannot outperform the returns from buy and hold strategy in Karachi stock exchange due to the high transaction cost of technical analysis. Moreover, Bukhardi, Cai, Hudson and Keasey (2005) studied the effect of size of the firm on technical trading rules. 33, 33, 34 companies from financial time stock exchange (FSTE) 100, FTSE 250 and FTSE small cap in London exchange had been selected randomly as stock data to analysis technical trading rules. The result suggested that technical trading rules have higher predicting power in small capitalization company.

\section{Fundamental Analysis vs Technical Analysis}

Survey studies and empirical studies had been used to determine the credibility of fundamental analysis and technical analysis in the previous literature. Liu and Mole (1998) conducted a questionnaire survey on the use of fundamental and technical analyses by foreign exchange dealers in Hong Kong. Their findings reveal that less than $85 \%$ of the respondents used both fundamental and technical to forecast exchange rate movements. However, their result stated that technical analysis is slightly useful in predicting turning point and forecasting trends compared to fundamental analysis. This result has been supported by Oberlechner (2001). The importance of technical and fundamental analysis in forecasting trend is verified. The result showed most of the traders use both analysis. Technical analysis is preferable in short time horizon thus he suggested technical analysis may become more important over the decades. Oppositely, Cohen, Kudryavtsev and Shlomit (2011) investigated the different approach used by professional portfolio managers to amateur investors by using survey research. The finding showed both of them use more frequently fundamental tools such as financial statement and recommendation by analysists compared to technical when making investment decision. A survey on the use of fundamental analysis and technical to forecast the movement of share price has conducted in 2011 by Venkatesh and Tyagi. They found that different approaches were used in different sectors. Fundamental analysis has been used to construct a strategy portfolio in conventional industries such as banking, cement, pharmacy and etc. while technical analysis has been used in modern sectors such as entertainment, telecom, real estate and et al. Another finding stated that brokers relied on different approaches in different time horizon (Kumar, Mohapatra \&Sandhu, 2013). Technical analysis is used for short time horizon whereas fundamental analysis is used for long time horizon.

Besides, empirical study is the second method. Moosa and Li (2001) investigated whether fundamental or technical analysis is more effective in Chinese stock market by using time series and 
panel data. Based on the results obtained from time series regression, although it showed that mix results for the effectiveness of fundamental trading and technical trading, effectiveness of technical trading is more significant. Through panel regression, both technical and fundamental trading showed important role in forecasting stock price. However, technical trading is more effective compared to fundamental trading in Chinese stock market.

Fundamental analysis is able to perform at a higher caliber compared to technical analysis if a low risk sample is used (Swart, 2011). The aim of the study is to observe the performance of fundamental and technical trading rule on European government bonds' yield spread from 2000 till 2010. Fiscal factor, economy factor of current state, liquidity factor and international risk factor had been used as the fundamental trading rule in the research. According to Bettman, Sault and Schultz (2009), their finding proved that fundamental and technical analysis served as complements instead of substitutes. Both can forecast the stock value well separately, but predicting power decreased when two model is combined. On the other hand, Lee \& Shih (2010) found that combined fundamental and technical information can improve the technical momentum strategy and thus generates large return for both of the growth and stock value. In another study by Neely, Tu, Rapach \& Zhou (2010) compared the predictive power of fundamental and technical trading rules by using out-of-sample tests for 1960-2008 in US equity premium. Their finding concluded that both of them are able to forecast gains which provide statistical and economical significant and largely complementary to each other in recessions of business cycle. There was different pattern in their performance in recession business cycle: fall in the equity premium near business cycle peaks is recognized by technical rules while rise in equity premium near business cycle troughs is recognized by fundamental rules. Suresh (2013) studied on fundamental and technical analysis on stock return. She suggested that fundamental and technical analysis are highly essential for investment decision. A similar study was conducted by Petrusheva and Jordanoski (2016), they compared the differences between fundamental analysis and technical analysis on stocks. Based on their comparison, they concluded that combining the fundamental analysis and technical analysis will lead to optimum results on stock due to the fact that both analyses have their advantages and disadvantages.

\section{Efficient Market Hypothesis}

Statisticians observed that stock prices seem to follow a fair game pattern in the past century which has led to the random walk hypothesis. It was introduced by Louis Bachelier, a French mathematician in 1900. Random walk hypothesis stated that prices of equities are following a random walk and unpredictable. In other words, changes of equities' price are independent of each other which means future movement cannot have predicted by past movement or trend. Random walk hypothesis. Although there were a few studies in the 1930's, random walk hypothesis is not well-known until it was being studies and debated intensively in the 1960's. Therefore, it can be concluded that the efficient market hypothesis strikes a similar understanding with the random walk hypothesis. Efficient Market Hypothesis (EMH) stated that financial markets are efficient and stock prices are informational efficient. According to Fama (1970), financial markets are considered efficient if the prices change rapidly with new information and without bias. Stock prices are informational efficient when all relevant information such as earning payment and future expectation as well is already built in to stock price. Efficient Market Hypothesis suggested that stocks will always trade at their fair value on the stock exchange, it is unlikely and difficult for an investor to outperform the market and get abnormal return in the stock market. In this theory it suggests that there are no undervalued or overvalued stocks, thus there is no way for investors to gain high return unless they invest in riskier investment. However, it has passionate discussion, debated between challengers and proponents and the arguments are often unclear. Others may have said that it is meaningless to forecast securities moving patterns in order to search for undervalued or overvalued stock under the efficient market hypothesis by using fundamental and technical analysis. Yet some successful analysts such as Warren Buffett, Peter Lynch and George Soros 
had consistently beaten the stock market over long period of time. (Clarke el al, 2011). There is some assumption of efficient market which are;

- All relevant information can be obtained by investors easily

- All these information investors obtained can be used to analyze economy and financial market for their investment decision

- Investors will get the information quickly when an event that give an impact of stock price happen such as unpredictable events, labor strikes and major lawsuit happen.

- Investor always respond almost as soon as new information pops out.

Based on market efficiency, efficient market theory can be distinguishing into three versions which are weak form, semi-weak form and strong form. In weak form of the efficient markets hypothesis declares that the current price is only based on the market trading information of past history such as stock price and trading volume (William 2016). Some theorists may think that efficient market hypothesis still can be accepted to a certain extent. They proposed that it is impossible to forecast the share prices and abnormal return. (Jeffery, 2010) In semi-strong level, it suggests that current price fully incorporates with public information other than market data and past prices but also includes news, financial statements of company, patents and et al. Although the information is more than weak- form efficiency, abnormal return is still unable to be generated due to the information is already known by all investors (Clarke el al, 2011). In strong level, it proposed that current price include all existing information which not only public information, but also private information. Normally, the private information is obtained from the corporate insider such as officers and executive of the corporation. Thus, the corporate insiders can make abnormal return by trading their company's stock before the information spread out. To avoid this from happening, Securities and Exchange Commission (SEC) has banned insider trading (William, 2016).

\section{Dow Theory}

Dow Theory stated that when one of the averages (Dow Jones Industrial Average (DJIA) or Dow Jones Transportation Average (DJTA)) increases, the counterpart tends to move up to the same level within a time period. If this doesn't happen, the averages will be said to show 'divergence' and causes the market to be subjected to reverse course. It is a form of technical analysis which is used to analyze market behavior and stock price movement and includes some parts of sector variation. Dow Theory is considered one of the earliest theories regarding technical analysis and it still serves as an initial basis to many other technical indicators (Reilly \& Keith, 2012). Charles H. Dow developed Dow Theory in 1900 but he did not manage to publish the complete theory due to his death in 1902. After his death, there are several associates William Peter Hamilton, Robert Rhea and E. George Schaefe which further studied the theory based on Dow's reviews and made most important contribution on Dow Theory. In order to help investor, get a better understanding about the market environment, there are six basic tenets of Dow Theory that investors need to know (Ray, 2012). There is an unusual history from perceptions of Dow Theory for timing purchased. From this technique, a "breakthrough" of the stock on the upside signals investors to buy and the "breakthrough" on the down side on the other hand signals investors to sell. Dow Theory is used to calculate the estimated result and showed an almost steady series of profits in operation from 1897 until 1960s. However, a closer study found that the quality of the theory had changed drastically after 1938. From Benjamin' perspective, Although the results of the Dow Theory show inherent characteristics of forecasting and trading formulae in both the business and finance field, the changes are not accidental (Benjamin, 1984). 


\section{RESEARCH MODEL AND METHODOLOGY}

\section{The Relationship between Fundamental Analysis and Stock}

Fundamental indicators are useful to forecast the stock return. Previous studies have showed that there is a relationship between fundamental analysis and stock return. In a study of Martani, Mulyono and Khairurizka (2009), it is found that Fundamental factors which are profitability (net profit margin and return on equity), total asset turnover and price to book value have a significant relationship with stock return. However, the leverage and the size of the firm does not have significant relationship on stock return. They applied the method on listed manufacturing companies on Indonesia stock market from year 2003 to 2006. There is a significant relationship between fundamental ratios and sock return in Tehran stock market (Karami \& Talaeei, 2013). The fundamental indicators which are price to earnings, book to market value, dividend yield and capital gain were used in the study. The result shown that price to earnings and book to market value has significant relationship with stock return. Muhammad and Scrimgeour (2014) investigated the impact of fundamental analysis on measurement the stock return on Australian stock market. Financial measure based (ROA, ROE, EPS, free cash flows and payout ratio) and market based (P/E, Tobin's Q, market to book ratio, market value added and cash flow return on investment) were used in the study. ROA and payout ratio have the most significant relationship with stock return.

Wijesundera et al. (2015) proposed that there is a significant relationship between fundamental analysis and stock return. They found that return on equity, earnings per share and book to market value is positively related to stock return by using Ordinary least squares (OLS) techniques. Khotimah and Murtaqi (2015) suggested that there is a significant relationship between fundamental analysis and stock return. They use current ratio, book to market and total asset turnover as the fundamental indicators. Based on their finding, current ratio is negatively correlated to stock return whereas book to market and total asset turnover is positively related to stock return. Hassan, Farooq and Muddassin (2015) examined the relationship between four fundamental indicators and stock return. They found that book to market value of equity and sales to price has a positive significant relationship with stock return, whereas there is a negative relationship between firm size and stock return. There is no significant relationship between debt to equity and stock return.

Anwaar (2016) studied the impact of fundamental variables of firms on the stock returns. The fundamental variables are earnings per share, quick ratio, return on assets, return on equity and net profit margin. Based on his finding, net profit margin and return on assets have the positive significant relationship with stock return whereas there is a negative relationship between earning per share and stock return. However, return on equity and quick ratio do not have relationship with stock return. According to Abardenell and Bushee (1997), macroeconomic variables may affect the correlation of fundamental indicators and expected stock return such as inflation, unemployment rate, Gross Domestic Product (GDP) and etc. Not only that, Seng and Hancock (2012) have found that contextual factors such as prior earning news and industry, country incorporation and macroeconomic variables can influence the predictive power of fundamental signals on stock price.

\section{The Relationship between Technical Analysis and Stock}

Ahmed, Beck and Goldreyer (2000) tested the efficiency of technical trading strategies in three Asian market by using five different variable moving average trading models. Based on their finding, they supported that the strong serial correlation among stock returns resulting from the effectiveness of trading model gives the model the ability to forecast future stock returns Sehgal and Garhyan (2002) proposed that generally technical analysis can produces positive significantly mean return in Indian capital market 
by using several technical indicators. On Balance Volume is the most powerful among others technical indicators which can be used in different phase of the market (bull or bear). Metghalchi at el (2007) applied two moving average technical trading rule in Austrian stock market to test the predictive power of technical trading rule in forecasting stock market return. They found that moving average have stronger predictive power which abnormal return can be generated and outperform buy and hold strategy.

Chong and $\mathrm{Ng}$ (2008) examined the effectiveness of technical analysis to produce excess return in London stock exchange by using 60 years' data. The result showed that Moving Average ConvergenceDivergence and Relative Strength Index are profitable which higher positive return can be generated compared to buy and hold strategy. Hartono and Sulistiawan (2015) also suggested higher return can be produced by using technical analysis compared to buy and hold strategies. Marshall, Qian and Young (2009) studies the ability of technical analysis to generate profit on US stock by using moving average as trading rule. They found that there is statistically significant relationship between technical analysis and stock return which profit can be generated. He also suggested that it is more profitable for small cap and less liquid stocks. Another study also proposed that positive significant return can be produced by using technical analysis (moving average and relative strength as indicators) in Singapore (Wong, Manzur \& Chew, 2003) Swart (2011) studies the ability of technical analysis to generate risk-adjusted return by using individual OLS, pooled OLS and FGLS panel estimation with time-fixed effect. Based on his finding, he found that technical analysis and risk-adjusted return are positively related to each other, and positive economic and significant risk-adjusted portfolio return can be generated. Ghobadi (2014) suggested that there is a relationship between technical analysis and stock return. He found that technical analysis can generate abnormal stock return. The technical indicators included stochastic oscillator, relative strength index, commodity channel index and money flow index. The technical indicators generated more return that London Interbank Offered Rate.

This study is a casual study which involves secondary data and a number of empirical techniques. All the secondary data are obtained from International Financial Data Stream, Bursa Malaysia and World Bank. There are 80 out of 85 manufacturing companies that provide sufficient information which listed in Bursa Malaysia are being chosen as the sample. The sample company should provide sufficient information on net profit margin, price earnings ratio, total asset turnover, moving average convergence divergence and date of incorporation for each sample company in order to determine the credibility of the fundamental analysis and technical analysis. The yearly data for the time period of year 2011 to 2015 . The regression test is carried out to analyze the relationship between the variables. Two multiple regression model, one model is for fundamental analysis and another is for technical analysis is used to determine the credibility of fundamental analysis and the technical analysis on stock return. There are four types of independent variables in this study which are net profit margin, price earnings ratio, total assets turnover and moving average convergence divergence. The stock return is the dependent variables.

\section{Fundamental analysis- model (1)}

Model (1) use to predict stock price for fundamental analysis can be written as functional relationship as below

$\mathrm{Pi}, \mathrm{t}=\alpha+\beta 1$ NPM i, $\mathrm{t}-1+\beta 2$ PE i, $\mathrm{t}-1+\beta 2$ TAT i, $\mathrm{t}-1+\mathcal{E}-(1)$

Where,

$\mathrm{P} \quad=$ Expected closing price of company

NPM = Net profit margin of company

PE = Price earnings ratio of company

TAT =Total assets turnover of company

$\alpha, \beta 1, \beta 2=$ Mathematical coefficients 
$\mathcal{E}=$ Randomized Errors

\section{Technical Analysis - model (2)}

The model (2) which is related to predict stock price is can be illustrate as following

$\mathrm{Pi}, \mathrm{t}=\alpha+\beta 1 \mathrm{MACD}$ i, $\mathrm{t}-1+\varepsilon$

Where,

$\mathrm{P} \quad=$ Expected closing stock price for company

$\mathrm{MACD}=$ Price that retrieved from Moving average convergence divergence

$\alpha, \beta 1, \quad=$ Mathematical coefficients

$\varepsilon=$ Randomized Errors

The symbols of $i$ and $t$ are the listed companies chosen and time dimension of the data

\section{Hypothesis}

Fundamental and technical analysis are used to forecast the stock return by using different approaches. However, technical analysis is more effective and more reliable to predict the value of stock (Moosa \& $\mathrm{Li}, 2001)$. Thus, the hypothesis is proposed as below:

H1: There is a relationship between stock return and net profit margin.

$\mathrm{H} 2$ : There is a relationship between stock return and price earnings ratio.

H3: There is a relationship between stock return and total asset turnover.

H4: Thereis a relationship between stock return and moving average convergence and divergence (MACD).

H5: Technical analysis outperform fundamental analysis in concerning the stock return.

\section{DATA ANALYSIS AND RESULTS}

The empirical results and findings of the study of 80 Malaysia food manufacture industry listed companies from the Main Market of Bursa Malaysia were being tested. The data period is from 2012 to 2016. There are few methods that used for empirical analysis which are descriptive statistic, Pearson Correlation Coefficient, Panel Regression Analysis and Diagnostic Test. The most suitable panel regression is determined.

\section{Descriptive Statistics}

The fundamental analysis showed that the mean of dependent variable stock return is 1.06 with the standard deviation of 5.88. The minimum value is -11.65 while the maximum value is 103.39 . This indicates that an average of RM1.06 of stock return is able to be generated through the investment made by investors. As the range value start from negative value, it reveals that investors might invest to some of the companies which might have poor performance. Not only that, turmoil within a broad sector or the economy and inflation might also reveal a negative return. One of the independent variable is net profit margin. The mean value is 8.24 with a standard deviation of 129.76 . The range of the value is from -1740 to 1612.68. The mean value indicates that all these listed companies in Bursa Malaysia has an average of net profit margin of 8.24 . The negative of the range value indicates that some of the companies might experience losses. For price earnings ratio, the mean value is 16.10 with the standard deviation of 39.96. The range is from 0 to 736. The mean value shows that investors are willing to invest for the company stock in Bursa Malaysia with an average companies' earnings of RM 16.10. Lastly, the mean value of 
total asset turnover is 0.71 . The range is from 0 to 5.33 with a standard deviation of 0.63 . The mean value reveals that RM0.71 revenues is generating through each ringgit's worth of asset of the companies.

The descriptive statistic of the stock return for technical analysis is same as the fundamental analysis. The mean value is 1.06 with a standard deviation 5.88. The minimum value is started from negative value which is -11.65 . When investors invest into the company with poor management or factors beyond its control, a negative return might occur. The independent variable for technical analysis is moving average convergence and divergence (MACD). The mean value is 0.007 with standard deviation 0.04 . The value is range from -0.13 to 0.58 . The mean value indicates the relationship between two moving averages price of listed companies in Bursa Malaysia which is at average of 0.007.

\section{Pearson Correlation Coefficient}

Table 1: Pearson Correlation between Dependent Variable and Independents Variables for Fundamental Analysis

\begin{tabular}{lllll}
\hline & SR & NPM & PE & TAT \\
\hline SR & 1.0000 & - & - & - \\
NPM & 0.0833 & 1.0000 & - & - \\
& $(0.0963)$ & & & - \\
PE & -0.0129 & 0.0092 & 1.0000 & \\
& $(0.7977)$ & $(0.8546)$ & & 1.00000 \\
TAT & 0.2327 & -0.0184 & -0.0133 & \\
& $(0.0000)$ & $(0.7133)$ & $(0.7902)$ & \\
\hline
\end{tabular}

The table 1 shows the Pearson Correlation between the stock return and the independent variable. There is a weak negative relationship between price earnings ratio and stock return. Total asset turnover shows a strong positive relationship with stock return whereas the net profit margin shows a weak positive relationship with the stock return.

Table 2: Pearson Correlation between Dependent Variable and Independents Variables for Technical Analysis

\begin{tabular}{lll}
\hline & SR & MACD \\
\hline SR & 1.0000 & - \\
MACD & 0.1199 & 1.0000 \\
& $(0.0165)$ & \\
\hline
\end{tabular}

Pearson correlation between dependent variable and independent variable is showed in table 2. It shows that moving average convergence and divergence has a positive relationship with the stock return. 


\section{Panel Regression Analysis and Diagnostic Test}

\section{Fundamental Analysis}

Table 3: Results of Panel Data Analysis for Fundamental Analysis.

\begin{tabular}{|c|c|c|c|}
\hline & Pooled OLS & $\begin{array}{l}\text { Random } \\
\text { effects }\end{array}$ & $\begin{array}{c}\text { Pooled OLS with } \\
\text { Robust Standard } \\
\text { Error }\end{array}$ \\
\hline NPM & 0.0040 & 0.0053 & $0.0039^{* * *}$ \\
& $(0.072)$ & $(0.084)$ & $-0.061)$ \\
\hline PE & -0.0015 & -0.0027 & $(0.841)$ \\
\hline TAT & $(0.829)$ & 2.1864 & $(0.554)$ \\
\hline Constant & 2.1803 & $(0.000)$ & $(0.042)$ \\
\hline $\begin{array}{c}\text { Breusch-Pagan LM } \\
\text { test }\end{array}$ & -0.4916 & -0.4936 & -0.4916 \\
\hline Observations & $(0.272)$ & $(0.291)$ & $-0.350)$ \\
\hline $\begin{array}{c}\text { Multicollinearity } \\
\text { (vif) }\end{array}$ & $4000)$ & & - \\
\hline $\begin{array}{c}\text { Heteroscedasticity } \\
\text { (x2-stat) }\end{array}$ & 1.00 & 400 & - \\
\hline $\begin{array}{c}\text { Serial Correlation } \\
\text { (F-stat) }\end{array}$ & $1.6 \mathrm{e}+06$ & - & - \\
\hline
\end{tabular}

Notes: $\quad S R=$ Stock return, $N P M=$ Net profit margin, $P E=$ Price earnings ratio $(P / E$ Ratio $)$, TAT $=$ Total Asset Turnover. Symbols $(*, * *, * *)$ show the statistical significance at various significant levels $(1 \%, 5 \%, 10 \%)$ respectively.

The panel data regression analysis for fundamental analysis of this study is showed in the table 3 . The result of Pooled OLS and RE model are showed in the table above. In order to choose the model that is suitable for data used, Breusch and Pagan LM test has been carried out. The p-value for Breusch and Pagan Lm test is 1.00 which is insignificant result to reject the H0. The result also shows that there is no multicollinearity problem in Pooled OLS model. This is due to the value for mean VIF is 1.00 which is less than 10. However, there is heteroscedasticity problem in the proposed Pool OLS model which shows in the result. The p-value of the heteroscedasticity is 0.000 which is less than 0.05 (5\% significant level). This indicate that the variance for the error term is not constant. Moreover, the p-value of the serial correlation test is 0.002 which is less than 0.05 (5\% significant level). It reveals that there is also autocorrelation problem in the proposed Pooled OLS model. As a result, the Pooled OLS with robust standard error was used as final regression model to correct the uneven variance of error term as there is heteroscedasticity and autocorrelation problem detected from the diagnostic check 


\section{Technical Analysis}

Table 4: Results of Panel Data Analysis for Technical Analysis.

\begin{tabular}{|c|c|c|c|}
\hline & Pooled OLS & $\begin{array}{l}\text { Random } \\
\text { effects }\end{array}$ & $\begin{array}{c}\text { Pooled OLS with } \\
\text { Robust Standard } \\
\text { Error }\end{array}$ \\
\hline MACD & $\begin{array}{l}17.5398 \\
(0.016) \\
\end{array}$ & $\begin{array}{l}17.5472 \\
(0.021) \\
\end{array}$ & $\begin{array}{c}17.5378^{* *} \\
(0.015) \\
\end{array}$ \\
\hline Constant & $\begin{array}{l}0.9493 \\
(0.001)\end{array}$ & $\begin{array}{l}0.9581 \\
(0.003)\end{array}$ & $\begin{array}{l}0.9493 \\
(0.000)\end{array}$ \\
\hline $\begin{array}{c}\text { Breusch-Pagan } \\
\text { LM } \\
\text { test }\end{array}$ & \multicolumn{2}{|c|}{$\begin{array}{r}0.00 \\
(1.00)\end{array}$} & - \\
\hline Observations & 400 & 400 & 400 \\
\hline $\begin{array}{l}\text { Multicollinearity } \\
\text { (vif) }\end{array}$ & 1.00 & - & - \\
\hline $\begin{array}{l}\text { Heteroscedasticity } \\
\text { (x2-stat) }\end{array}$ & $\begin{array}{l}8.6 e+06 \\
(0.000)\end{array}$ & - & - \\
\hline $\begin{array}{c}\text { Serial Correlation } \\
\text { (F-stat) }\end{array}$ & $\begin{array}{l}138.016 \\
(0.0000)\end{array}$ & - & - \\
\hline
\end{tabular}

Notes: $S R=$ Stock return, MACD = Moving Average Convergence Divergence, The symbols $(*, * *, * * *)$ show the statistical significance at various significant levels $(1 \%, 5 \%, 10 \%)$ respectively.

The table 4 above shows the panel data regression analysis for technical analysis of this study. In order to determine the relationship between stock return and moving average convergence and divergence, Pooled Ordinary Least Square (Pooled OLS) model and Random Effect (RE) model are implies in this study. Breusch and Pagan LM test is used to choose the more suitable model between Pooled OLS and RE model. The result shows that the Pooled OLS model is more suitable than RE model. This is due to the p-value for Breusch and Pagan LM test is 1.00 which is statistically insignificant. Therefore, Pooled OLS model has been chosen. Since Pooled OLS model is selected, there might have some multicollinearity, heteroscedasticity and autocorrelation problems exist. Therefore, diagnostic checks are carried out to detect the problem in order to maintain the robustness and validity of data. The value for mean VIF is 1.00 which is less than 10. This indicates that there is no multicollinearity problem in Pooled OLS model. Furthermore, the p-value of the heteroscedasticity is 0.000 which is less than 0.05 (5\% significant level). There is statistically significant result show that there is heteroscedasticity problem in the proposed Pool OLS model. This might due to the non-constant of variance of error term. Furthermore, the result shows that there is autocorrelation problem in the proposed Pooled OLS model as the p-value of the serial correlation test is 0.000 which is less that 0.05 (5\% significant level). Since there is heteroscedasticity and autocorrelation problem detected in the proposed Pooled OLS model, Pooled OLS with robust standard error was used to precise the uneven variance of error term. Therefore, the Pooled OLS with robust standard error is selected as the final regression model. The p-value for moving average divergence convergence is 0.015 which is lower than 0.05 (5\% significant level) which shows statistically significant positive relationship between stock return and moving average convergence and divergence. The coefficient of MACD is 17.5378 which determines that moving average divergence and convergence of the picked stock(s) by investors increase by 17.5378 unit will increase stock return of investors by 1 unit. 


\section{Fundamental analysis vs Technical analysis}

Table 5: Fundamental Analysis vs Technical Analysis

\begin{tabular}{|l|c|c|}
\hline & Fundamental Analysis & Technical Analysis \\
\hline R-squared & 0.0619 & 0.0144 \\
\hline Adj. R-squared & 0.0548 & 0.0119 \\
\hline Sum squared residual & 12928.6957 & 13584.1132 \\
\hline Root mean squared error & 5.7139 & 5.8422 \\
\hline Probability (F test) & $0.0890^{* * *}$ & $0.0154 * *$ \\
\hline
\end{tabular}

The table 5 above show the comparison of result between fundamental analysis and technical analysis. The probability of $\mathrm{F}$ test in both model get a high degree of precision at significance levels of $10 \%$ which verifies that both models are predictable. Besides, R-squared and adj. R-squared for fundamental analysis is 0.0619 and 0.0548 respectively whereas for technical analysis is 0.0144 and 0.0119 . Both value for fundamental analysis is higher than technical analysis which indicates that fundamental analysis is slightly superior over the technical analysis. Besides that, the S.E of regression and the value of sum squared residuals for fundamental analysis model is lesser than technical analysis model. These results show the technique of fundamental analysis is slightly superior over technical analysis in the food manufacturing sector.

\section{Hypothesis results}

Table 6: Hypotheses Results

\begin{tabular}{|l|l|}
\hline Hypotheses & Action \\
\hline H1: There is a relationship between stock return and net profit margin. & Fail to accept \\
\hline H2: There is a relationship between stock return and price earnings ratio. & Fail to accept \\
\hline H3: There is a relationship between stock return and total asset turnover. & Accepted \\
\hline $\begin{array}{l}\text { H4: There is a relationship between stock return and moving average } \\
\text { convergence and divergence (MACD). }\end{array}$ & Accepted \\
\hline $\begin{array}{l}\text { H5: Technical analysis outperform fundamental analysis in concerning } \\
\text { the stock return }\end{array}$ & Fail to accept \\
\hline
\end{tabular}

There are many investors that make use of fundamental analysis to assess the situation of a company whether it is worth to invest so that they could generate profit from their investment. By using fundamental analysis, investors could yield a positive result. From the table 6, it shows that $\mathrm{H} 3$ do not have enough evidence to be accepted while $\mathrm{H} 1$ and $\mathrm{H} 2$ were failed to accept. Firstly, the empirical result showed that the total asset turnover has the significant positive relationship with the stock return. Total asset turnover ratio is one of the efficiency ratio that use to measures the efficiency of a company use its asset to generate sales. Higher total asset turnover ratio indicates the better the company is performing which can give a positive effect on stock return. According to a study of Alexis, Patra and Poshakwale (2010), asset turnover is positively related to stock return by using panel data analysis whereas the net profit margin is insignificant to stock return. Not only that, Khotimah and Murtaqi (2015) stated total asset turnover has impact on stock return as the good management of companies' assets to generate 
revenue result in higher return. This is due to the fact that the greater performance of a company, the higher stock price which result in greater stock return.

Besides, the price earnings ratio helps investors to analyze how much they should pay for a stock based on current earnings. Price earnings ratio can be used to compare the relative earnings power of the companies and it also reflect the expectation of the market concerning the future performance of the stock. Although it is insignificant in this study, but it shows a negative relationship toward stock return which means the lower the PE ratio, the higher the stock return. This has supported by the study of Campbell and Shiller (1998), they found that the PE ratio was negatively corrected with the stock price. This is due to a stock with high PE ratio may be overpriced, investors need to pay more for the stock, thus lower stock return. According to the study of Gacheri (2014), the empirical result showed that there is no significant relationship between stock return and price earnings ratio. From the findings of Tripathi (2008), he also proposes that there is no relationship between price earnings ratio and stock return. Last but not least, the net profit ratio is one of the profitability ratio which show financial efficiency of a company. Net profit margin can be used to measure of the overall success of a business as it can subject to a variety of issues such as leveraged situations, accounting compliance, short term focus and etc. In this study, net profit margin shows a positive relation towards stock return while price earnings ratio shows a negative relation towards stock return. Although both variables are not significant in this study, it still has the predictive power on stock return. It is due to different countries and different sectors might propose different result of fundamental indicators on the stock return. From the study of Dita and Murtaqi (2014), their findings show that net profit margin has positive significant impacts to the stock return in Indonesian customer goods industry. However, Chan, Yap and Asri (2012) stated that there is no significant relationship between stock return and net profit margin in Malaysia property sector.

Fundamental analysis involves variety of aspect to assess a company such as revenue, expenses, liabilities, asset and other financial aspects of a company which can help investors to evaluate the company before making an investment decision (Nadeem, Sajid \& Muhammad, 2013). Most of the fundamental analysts look at this information to evaluate the performance of the company and also gain insight on its future performance. Thus, fundamental indicators are useful to forecast the price movement and generate positive return.

For technical analysis, the result shown in table 6 revealed that $\mathrm{H} 4$ have enough evidence to be accepted where moving average convergence and divergence is statistically significant to stock return at $5 \%$ significant level and shows a positive relationship with stock return. Nowadays, technical analysis is widely used by investors especially for investors who like to invest in short term investment. There are lots of technical indicators such as stochastic oscillator, relative strength index and etc. According to the study of Swart (2011), he suggests that there is a positive relationship between the risk-adjusted return and technical analysis. Wafi (2015) also proposes that technical analysis can be used to forecast stock return performances and generate positive return. Besides, from the study of Chong and $\mathrm{Ng}$ (2008), they stated that moving average convergence and divergence can be used to generate stock return. Technical analysts differ from fundamental analysts, they only focus on the market trend by using technical indicators to forecast the future stock price and movement instead of analyze the intrinsic value of the stock (Suresh, 2013). Technical analysis gives the signal to investors to enter the market in the right time to buy or sell stock in to gain the maximum profit.

The empirical results have proven that both analysis are able to predict stock return and generate positive return. However, from the table 6 above, it shows that the H5 is rejected which indicate technical analysis did not outperform fundamental analysis. 


\section{CONCLUSION}

The Investors always questions about which technique is the best, fundamental analysis or technical analysis in order to gain the maximum profit from their investment. Both analysis is used to forecast stock return by using different approach (Murphy, 1999). From the study of Cohen, Kudryavtsev and Shlomit (2011) proposed that most of the professional portfolio managers to amateur investors use more frequently fundamental indicators compared to technical when making investment decision. This has proven that the fundamental analysis is useful to generate positive return. Besides, Fundamental analysis is able to perform at a higher caliber compared to technical analysis if a low risk sample is used (Swart, 2011). In this study, it stated that technical analysis did not outperform fundamental analysis. However, the result of this study contrast with the study of Needly (2010), Moosa \& Li (2011) and also Wafi (2015). Based on their findings, they stated that technical analysis is more effective compared to fundamental analysis. This might due to the fact that different sectors and country used will show different results. According to Venkatesh \& Tyagi (2011), they found that different approach was used in different sectors. Fundamental analysis has been used to strategy portfolio in conventional industries such as banking, cement, pharmacy and et al while technical analysis has been used in modern sectors such as entertainment, telecom, real estate and et al. Moreover, Oberlechner (2001) proposed that technical analysis is preferable in short time horizon whereas fundamental analysis is more suitable for long time period. This showed that time period will affect the result of the study also. Nevertheless, according to Suresh (2013), she suggested fundamental and technical analysis both of them are important to make investment decision although both of them using different method to forecast the stock return. Furthermore, Petrusheva and Jordanoski (2016) concluded that fundamental analysis and technical analysis have their advantages and disadvantages, therefore combined both analysis will lead to optimum results on stock.

In conclusion, both analysis is useful in helping investors to generate positive return. However, there is no better way in deciding which approach is better as the reliability of both analysis depends on the occasion. There is some limitation of this study where the data gained is only from food manufacturing sectors in the main market of Bursa Malaysia from 2012 to 2016. The restriction of the sectors and the country may cause the result of this study different from other studies. On top of that, the time period involved for this study is only 5 years which may affect the inaccuracy of the data. Lastly, there are lots of indicators for fundamental analysis and technical analysis. However, there are only three indicators and one indicators respectively used in this study which may cause insufficient factors in explaining the relationship towards stock return. The precision in comparison between the two models may be affected also. There is some suggestion for future research can be done in other industries instead of only focusing on food manufacturing industry. This is due to different industries may proposed different results on credibility on fundamental analysis and technical analysis. Furthermore, the number of sample and the time period can be increased in order to improve the reliability of the study. The number of indicators for both analyses can be increased as there are many types of indicators. By adding more indicators, not only can increase the accuracy of the data, the relationship towards stock return can be explained sufficiently also. Accuracy and usefulness of the indicators chosen can be tested by using out of sample given. Lastly, the forecast models for fundamental analysis and technical analysis can be added in the further study to increase the credibility of the study in comparing the predicting power of both model.

\section{REFERENCES}

Abarbanell, J.S., Bushee, B.J. (1997). Fundamental analysis, future earnings and stock price. Journal of Accounting Research, 35(1), 1-24.

Abarbanell, J.S., Bushee, B.J. (1998). Abnormal returns to Fundamental analysis strategy. The Accounting Review, 73(1), 19-45. 
Abbasi, E. \& Pagghe, M.A. (2013). The relationship between inflation, price-earnings ratio (P/E) and price behavior of Stock Tehran Stock Exchange. International Research Journal of Management Science, 1(4), 98-104.

Ahmed, P., Beck, K. \& Goldreyer, E. (2000). Can moving average technical trading strategies help in volatile and declining markets? A study of some emerging Asian markets. Managerial Finance, 26(6), 49-62.

Al-Abdulqader, K.A., Hannah, G. \& Power, D.M. (2007). The appraisal of ordinary shares by Saudi investors. Research in International Business and Finance, 21, 69-86.

Alexakis, C., Theophano, P., \& Poshakwale, S. (2010). Predictability of Stock Returns using Financial Statement Information: Evidence on Semi-Strong Efficiency of Emerging Greek Stock Market. Applied Financial Economics, 20 (16), 1321- 1326.

Allozi, N.M. \& Obeidat, G. S. (2016). The relationship between stock return and financial indicators (Profitability, Leverage): An empirical study on manufacturing companies listed in Amman Stock Exchange. Journal of Social Science, 5(3), 411- 424.

Almumani, M.A (2014) Determinants of equity share price of the listed banks in Amman stockexchange: Quantitative Approach. International Journal of Business and Social Science, 5(1), 91-104.

Anwaar, M. (2016). Impact of firms' performance on stock returns. (Evidence from listed companies of FTSE Index London, UK). Global Journal of Management and Business Research, 16(1), 31-39.

Asif, M., Arif, K., Akbar, W. (2016). Impact of accounting information on share price: Empirical evidence from Pakistan stock exchange, International Finance and Banking 3(1), 125-135.

Atrill, P. (1997). Financial Management for Decision Makers Sixth Edition. Italy: Pearson Education Limited.

Benjamin, G. (1984). The Intelligent Investor. New York: Harper Collins Publisher.

Berzkalne, I. \& Zelgalve, E. (2014). Return on equity and company characteristics: An empirical study of industries in Latvia. The 8th International Days of Statistics and Economics, 94-103.

Bessembinder, H., \& Chan, K. (1995). The profitability of technical trading rules in the Asian stock markets. Pacific-Basin Finance Journal, 3, 257-284.

Bettman, J. L., Sault, S. J., \& Schultz, E. L. (2009). Fundamental and technical analysis: substitutes or complements? Accounting \& Finance, 49(1), 21-36.

Bokhari, J., Cai, C., Hudson, R. \& Keasey, K. (2005). The predictive ability and profitability of technical trading rules: does company size matter? Economics Letters, 86, 21-27

Brock, W., Lakonishok, J., \& LeBaron, B. (1992). Simple technical trading rules and the stochastic properties of stock returns. Journal of Finance, 47, 1731-1764.

Campbell, J. Y. \& Robert J. S. (1998). Valuation ratios and the long-run stock market outlook. Journal of Portfolio Management, 24(2), 11-26.

Capital Group (2016). World market review for October 2016. Retrieved from https://www.thecapitalgroup.com/us/insights/market-commentary/world- markets-october2016.html\#

Chan, K.T., Yap, V.C. \& Asri, N. Q. (2012). Stock performance of the property sector in Malaysia. Journal of Modern Accounting and Auditing, 8(2), 241-246.

Chauhan, A. A. (2014). The study preference of portfolio managers towards fundamental and technical analysis as a decision making tool for investing in the equity markets: Navsari City. Kadakia International Journal of Research in Multidiscipline, 1(2), 169-180.

Cheung, Y. W. \& Ching, M. D. (2001). Currency traders and exchange rate dynamics: A survey of US market, Journal of International Money and Finance, 20, 439-471.

Chong, T. L. \& Ng, W. K. (2008). Technical Analysis and the London Stock exchange: Testing the MACD and RSI Rules Using the FT30. Applied Economics Letter, 15, 1111-1114.

Chong, T.L., Ng, W. K. \& Liew, K. S. (2014). Revisiting performance of MACD and RSI Oscillators. Journal of Risk and Financial Management, 7, 1-12. 
Clarke, J., Tomas, J, \& Gershon, M. (2001). The efficient markets hypothesis. Expert Financial Planning: Advice from Industry Leaders, Chapter 9, 126-141. New York: Wiley.

Cohen, G., Kudryavtsev, A. \& Shlomit, H.S. (2011). Stock market analysis in practice: Is it Technical or Fundamental? Journal of Applied Finance \& Banking, 1(3), 125- 138.

Constable, S. (2016). Fundamental bs. Technical stock analysts. Retrieved from http://www.wsj.com/articles/fundamental-vs-technical-stock-analysts- 1473127202.

Coutts, J.A. \& Cheung, K.C. (2000). Trading rules and stock returns: some preliminary short run evidence from the Hang Seng. Applied Financial Economics, 10, 579- 586.

Dita, A. H. \& Murtaqi, I. (2014). The effect of net profit margin, price to book value and debt to equity ratio to stock return in Indonesian customer goods industry. Journal of Business and Management. 3(3), 305-315.

Dow, C., Russell, R., Carlson, C., Shread, P. \& Sether, L. (2009). Dow theory unplugged: Charles Dow's original editorials and their relevance, First edition, W\&A Publishing, Cedar Falls, IA.

Dow Theory Basic Tenents, (2016). Market Technicians Association. Retrieved from https://www.mta.org/kb/dow-theory-basic-tenets/

Drakopoulou, V. (2015). A review of fundamental and technical stock analysis technique. Journal of Stock \& Forex Trading, 5(1), 1-8.

Er, S. \& Vuran, B. (2012). Factors affecting stock returns of firm quoted in ISE Market: A dynamic panel dara approach. International Journal of Business and Social Research, 2(1), 109-122.

Fama, E. F. (1970). Efficient capital markets: A review of theory and empirical work. The Journal of Finance, 25(2), 383-417.

Frase, L., \& Ormiston, A. (2004). Understanding Financial Statements. New Jersey: Pearson Prentice Hall.

Ghobadi, M. (2014). Profitability of technical analysis indicators to earn abnormal returns in International Exchange Market. Journal of Economics, Finance and Accounting, 1(4), 334-346.

Graham B, Dodd D (1996). Security Analysis: The Classic 1934 Edition, McGraw-Hill, New York, NY.

Hartono, J. \& Sulistiawan, J. (2015). Performance of technical analysis in declining global markets. Global Journal of Business Research, 9(2), 41-52.

Hassan, S.S, Farooq, S. \& Muddassir. M. (2015). Stock return indicators: Debt to equity, book to market, firm size and sales to price. Journal of Poverty, Investment and Development, 16, 25-32.

Hooke, C. J. (2010). Security analysis and business valuation on Wall Street: A comprehensive guide to Today's valuation methods, 2nd Edition, New Jersey: John Wiley\& Son Inc.

Hou, K. W., Kho, B. K. \& Karolyi, G.A. (2011). What factors drive global stock returns? Review of Financial Studies, 24(8), 2527-2574.

Hudson, R., Dempsey, M. \& Keasey, K. (1996). A note on the weak form efficiency of capital markets: The application of simple technical trading rules to UK stock prices - 1935 to 1994. Journal of Banking \& Banking, 20, 1121- 1132.

Jagongo, A. \& Mutswenje, V.S. (2014). A survey of the factors influencing investment decision: The case of individual Investors at NSE, International Journal of Humanities and Social Science, 4(4), 92-102.

Jeffrey E. J. (2010). Efficient markets hypothesis and daily variation in small Pacific- basin stock markets. Management Research Review, 33 (12), 1128 - 1139.

John, P. (2004). Complete Guide to Technical Trading Tactics: How to Profit Using Pivot Points, Candlesticks \& Other Indicators. Hoboken: John Wiley \& Sons.

Karami, G. R. \& Talaeei, L. (2013). Predictability of stock returns using financial ratios in the companies listed in Tehran Stock Exchange. International Research Journal of Applied and Basic Sciences, 5(3), 360-372.

Kheradyar, S., Ibrahim, I., Mat, N.F. (2011). Stock return predictability with financial ratio. International Journal of Trade, Economic and Finance, 2(5), 391-396.

Khotimah, K. \& Murtaqi, I. (2015). The fundamental analysis of Indonesian stock return. Journal of Business and Management, 4(1), 95-104. 
Kumar, N., Mohapatra, S. \& Sandhu, G. (2013). Importance of technical and fundamental analysis and other strategic factors in the Indian stock market, Management Review: An International Journal, 8(1), 38-75.

Lee, F.C. \& Shih, K. W. (2010) Technical, fundamental, and combined information for separating winners from losers, Working Paper Series, Retrieved from https://papers.ssrn.com/sol3/papers.cfm?abstract_id=1590460.

Lento, C., N. Gradojevic, \& C. Wright. (2007). Investment information content in Bolinger Band. Applied Financial Economics Letter, 3, 263-267.

Liem, P.F. \& Basana, S. R. (2012). Price earnings ratio and stock return analysis. Jurnal Manajemen dan Kewirausahaan, 14(1), 7-12.

Lo, A.W., Mamaysky, H. \& Wang, J. (2000). Foundations of technical analysis: computational algorithms, statistical inference, and empirical implementation. The Journal of Finance, 55(4), 1705-1765.

Lui, Y. H. \& Mole, D. (1998). The use of fundamental and technical analysis by foreign exchange dealers, Hong Kong evidence, Journal of International Money and Finance, 17(3), 535-545.

Marshall, B. R., Qian, S. \& Young, M. (2009). Is technical analysis profitable on US stocks with certain size, liquidity or industry characteristics? Applied Financial Economics, 19(15), 1213-1221.

Martani, D., Mulyono, and Khairurizka, R., (2009), The effect of financial ratios, firm size, and cash flow from operating activities in the interim report to the stock return, Chinese Business Revies, $8(6), 44-55$.

Mckenzie, M.D. (2007). Technical trading rule in emerging markets and 1997 Asian currency crises. Emerging Markets Finance and Trade, 43(4), 46-73.

Metghalchi, M., Chang, Y.H., \& Xavier, G.G. (2012). Technical analysis of the Taiwanese stock market. International Journal of Economics and Finance, 4(1), 90-102.

Metghalchi, M., Chang, Y. \& Marcucci, Y. (2008). Is the Swedish Stock Market Efficient? Evidence from Some Simple Trading Rules. International Review of Financial Analysis, 17(3), pp.475490.

Metghalchi, M. Du, J.J., \& Ning, Y.X. (2009). Validation of moving average trading rules: Evidence from Hong Kong, Singapore, South Korea, Taiwan, Multinational Business Review, 17 (3), 101 122.

Metghalchi, M., Yong, G., Xavier, G.G. \& Chen, C. (2007). Profitable technical trading rules for Austrian stock market. International Business \& Economics Research Journal, 6(9), 49-58.

Mitra, S. K. (2011). Usefulness of moving average based trading rules in India. International Journal of Business and Management, 6(7), 199-206.

Moosa, I. \& Li, L. (2011) Technical and fundamental trading in the Chinese stock market: Evidence based on time-series and panel data, Emerging Markets Finance and Trade, 47(1), 23-31.

Muhammad, N. \& Scrimgeour, F. (2014). Stock return and fundamentals in Australian market. Asian Journal of Finance and Accounting, 6(1), 271-290.

Murphy, J. (1999). Technical Analysis of the Financial Markets: A Comprehensive Guide to Trading Methods and Applications. New York: New York Institute of Finance.

Nadeem, I., Sajid, R. K. \& Muhammad, A. K. (2013). Does fundamental analysis predict stock returns? Evidence from non-financial companies listed on KSE. Knowledge Horizons, 5(4), 182-190.

Neely, J.C., Rapach, E.D., Tu, J. \& Zhou, G. (2010). Out-of-sample equity premium prediction: Fundamental vs. Technical analysis, Research collection Lee Kong Chain School of Business paper No. 3063, from https://www.kevinsheppard.com/images/5/51/Neely_Rapach_Tu_Zhou.pdf.

Oberlerchner, T. (2001). Importance of technical and fundamental analysis in the European foreign exchange market, International Journal of Finance and Economics, 6(1), 81-93.

Oplatek, J. (2007). Technical Analysis. Retrieved from http://is.muni.cz/el/1456/podzim2007/PFFMRA/um/Microsoft_PowerPoint_-_9. 
Ou, J.A \& Penman, S.H. (1989). Financial statement analysis and the prediction of stock returns. Journal of Accounting and Economics 11, 295-329.

Ozlen, S. \& Ergun, U. (2012). Macroeconomic factors and stock return. International Journal of Academic Research in Business and Social Science, 2(9), 315-343.

Park, C., \& S. Irwin. (2007). What do we know about the profitability of technical analysis? Journal of Economic Surveys, 21(4), 786-826.

Paul, R.L.M. (2016). Warren Buffett is beating the market again. Retrieved from http://money.cnn.com/2016/04/25/investing/warren-buffett-berkshire-hathaway- stock-annualmeeting/

Petrusheva, N., Jordanoski, I. (2016). Comparative analysis between the fundamental and technical analysis of stocks. Journal of Process Management, 4(2), 26-31.

Qi, M., \& Y. Wu. (2005). Technical Trading-Rule Profitability, Data Snooping, and Reality Check: Evidence from the Foreign Exchange Market. Journal of Money, Credit and Banking, 38, 2135 2158.

Ray, J. (2014). The 4 basic stock market index facts $\mathrm{u}$ should know. Retrieved from http://klse.i3investor.com/blogs/iisb/66560.jsp.

Ray, S. (2012). Revisiting the strength of Dow theory in assessing stock price movement. Advances in Applied Economics and Finance, 3(3), 591-598.

Reilly, B. \& Keith, C. B. (2012). Analysis of Investments \& Management of Portfolios, Tenth International Edition. Canada: Cengage Learning.

Riaz, S., Liu, Y.P., \& Khan, S.H. (2015). Exploring the relationship between market value and accounting numbers of firms in Pakistan. Asian Journal of Finance and Accounting, 7(1), 230238.

Schwager, J. (1999). Getting Started in Technical Analysis. New York: John Wiley \& Sons.

Seetharaman, A. \& Rudolph, J.R. (2011). An empirical study on the impact of earning per share on stock prices of a listed bank in Malaysia. Journal of Applied Economics and Finance, 5(2), 114-12.

Seng, D. \& Hancock, J.R. (2012). Fundamental analysis and the prediction of earnings. International Journal of Business and Management, 7(3), 32-46.

Sharma, S. (2011). Determinants of equity share price in India. Journal of Arts, Science and Commerce, 2(4), 51-60.

Sharma, M. \& Preeti. (2009). Prediction of stock returns for growth firms- Fundamental analysis. The Journal of Business Perspective, 13(3), 31-40.

Sehgal, S. \& Garhyan, A. (2002). Abnormal Return Using Technical Analysis: The Indian Experience. Finance India, 16 (1), 181-20.

Sohail, M. K. \& Jenhanzeb (2015). Does technical analysis generate superior profits? A study of KSE100 index using simple moving average. City University Research Journal, 5(2), 338-348.

Srinivasan, P. (2012). Determinants of equity share price in India: A panel data approach. The Romanian Economic Journal, 15(46), 205-228.

Suresh, A.S (2013). A study on fundamental and technical analysis. International Journal of Marketing, Financial Services \& Management Research, 2(5), 44-59.

Suzana, B., Sinisa, B. \& Zoran, I. (2012). Strategy of Stock Valuation by Fundamental Analysis. UTMS Journal of Economics, 4 (1), 45-51.

Swart, D. J. (2011). Are fundamental \& technical analysis able to generate significant risk-adjusted returns on European Government Bonds? Erasmus University Rotterdam.

Tijjani, B., Fifield, S.G.M. \& Power, D.M. (2009). The appraisal of equity investments by Nigerian investors. Qualitative Research in Financial Markets, 1, 6 - 26.

Venkatesh, C.K. \& Tyagi, M (2011) Fundamental analysis as a method of share valuation comparison with technical analysis, Bangladesh Research Publication Journal, 5(3), 167-174

Wafi, A. S., Hassan, H., \& Mabrouk, A. (2015a). Fundamental analysis vs technical analysis in the Egyptian stock exchange-Empirical study. International Journal of Business and Management Study-IJBMS, 2(2), 212-218. 
Wafi, A. S., Hassan, H., \& Mabrouk, A. (2015b). Fundamental analysis models in financial marketsReview study". Procedia Economics and Finance, 30, 939-947.

Wang, J., Fu, G., \& Luo, C. (2013). Accounting information and stock price reaction of listed companies - empirical evidence from 60 listed companies in Shanghai Stock Exchange. Journal of Business \& Management, 2(2).

Wang, I., Haslam, J. \& Marston, C. (2007). The appraisal of ordinary shares by financial analysts in China. BAA Conference, London.

Wijesundera, A. A. V. I., Weerasinghe, D. A. S., Krishna, T. P. C. R., Gunawardena, M. M. D. \& Peiris, H. R. I. (2016). Predictability of stock returns using financial ratios: Empirical evidence from Colombo Stock Exchange. Kelaniya Journal of Management, 4(2), 44-55.

William, C. S. (2016). The Random Walk and the Efficient Market Hypotheses. Retrieved from http://thismatter.com/money/investments/random-walk-efficient market-hypotheses.htm.

Wong, P.H. \& Ghafar, M.A.A (2015). The impact of accounting earnings on stock return: The case of Malaysia's Plantation industry. International Journal of Business and Management, 10(4), 155165.

Wong, W. K., Manzur, M. \& Chew, B. K. (2003). How rewarding is technical analysis? Evidence from Singapore stock market. Applied Financial Economics, 13(7), 543- 551.

$\mathrm{Wu}, \mathrm{W}$. T. (2014). The P/E ratio and profitability. Journal of Business \& Economics, 12(1), 67-76.

Corresponding Author: Shaharudin Jakpar can be contacted at jshaharudin@unimas.my 